\title{
Příspěvek k poznání vodních měkkýšů Vsetínské Bečvy a okolí (Česká republika) \\ Contribution to the knowledge of aquatic molluscs of the Vsetínská Bečva River and its surroundings (Czech Republic)
}

\author{
LUBOŠ BERAN \\ Agentura ochrany prírody a krajiny ČR, Správa Chráněné krajinné oblasti Kokořinsko, Česká 149, CZ-27601 Mělník, \\ e-mail:lubos.beran@nature.cz
}

BERAN L., 2007: Příspěvek k poznání vodních měkkýšů Vsetínské Bečvy a okolí (Česká republika) [Contribution to the knowledge of aquatic molluscs of the Vsetínská Bečva River and its surroundings (Czech Republic)]. - Malacologica Bohemoslovaca, 6: 35-44. Online serial at <http://mollusca.sav.sk> 20-Nov-2007.

\begin{abstract}
This paper brings a review of a malacological survey of the Vsetínská Bečva River, its tributaries, canals and other different aquatic habitats in surroundings (Eastern Moravia, Czech Republic). Vsetínská Bečva is a 58 $\mathrm{km}$ long river which rises in $870 \mathrm{~m}$ a.s.l. and joins Rožnovská Bečva River in Valašské Meziříčí at $288 \mathrm{~m}$ asl. Research was focused on endangered bivalve Unio crassus. Aquatic molluscs at 63 sites were studied in 2007. Altogether 19 species of aquatic molluscs (12 gastropods, 7 bivalves) were found. Three non-native species Potamopyrgus antipodarum, Physella acuta, and Gyraulus parvus, which are rare in Moravia, were found. Occurrence of vulnerable but in this region relatively common prosobranch Bythinella austriaca was confirmed in springs and rivulets. Research based on bivalves provided more interesting results. Existence of two large populations of Unio crassus were documented in two canals (mill races) in Hovězí and Vsetín. Populations of Unio crassus were estimated at 1500-2500 individuals in Hovězí and 1000-4000 individuals in Vsetín. Occurrence of young individuals of Unio crassus were confirmed in both cases. Rare bivalves Pisidium amnicum and P. moitessierianum were found at one site in Canal in Vsetín and also non-native Dreissena polymorpha was found at one site - the gravel pit near Nový Hrozenkov.
\end{abstract}

Key words: Mollusca, Vsetínská Bečva River, faunistics, Unio crassus

\begin{abstract}
Úvod
Průzkum Vsetínské Bečvy, jejích přítoků, náhonů a jiných vodních stanovišt' $\mathrm{v}$ nivě Bečvy byl proveden $\mathrm{z}$ důvodů nedostatečných znalostí o vodní malakofauně tohoto regionu, ale především s ohledem na relativně nedávné nálezy celoevropsky ohroženého a zároveň evropsky významného druhu velkého mlže a to velevruba tupého (Unio crassus) v náhonech Vsetínské Bečvy u Hovězí a ve Vsetíně. Tyto nálezy byly hlavním impulsem pro podrobnější průzkum území.
\end{abstract}

\section{Metodika a materiál}

Historická data byla získána z autorovy databáze, která obsahuje přepis dostupných publikovaných i nepublikovaných prací, údaje získané z kartoték a sbírek muzeí a od jiných malakologů. Údaje o současném rozšíření použité v této práci jsou získané terénním průzkumem autora. Průzkum byl proveden v roce 2007 na 63 lokalitách na toku Vsetínské Bečvy mezi Velkými Karlovicemi a soutokem s Rožnovskou Bečvou ve Valašském Meziř́ičí. Kromě vlastní Bečvy byly prozkoumány některé její pří- toky a to obvykle blízko ústí do Bečvy, dále vybraná prameniště a několik vodních nádrží v nivě Bečvy. Vzhledem $\mathrm{k}$ tomu, že průzkum byl zaměřen zejména na výskyt velevruba tupého (Unio crassus), byly nejpodrobněji prozkoumány náhony Bečvy a to zejména ty, kde byl výskyt tohoto druhu zjištěn (náhon ve Vsetíně a v Hovězí). Sběr byl na většině lokalit prováděn kombinací vizuální metody a odběrů sedimentu za pomoci kovového kuchyňského cedníku (průměr $20 \mathrm{~cm}$, velikost ok 0,5-1 mm).

Materiál získaný při průzkumu byl ve většině případů určen na místě a vrácen na lokalitu. $\mathrm{V}$ případě vzácných druhů (v tomto prrípadě Unio crassus, Gyraulus parvus) byla alespoň část sběru uložena do sbírky autora. U druhů determinovatelných pouze pomocí lupy (např. většina druhů r. Pisidium) byl materiál determinován až v laboratoři. Žádní jedinci nebyli determinováni pomocí pitvy, resp. to nebylo zapotřebí. Systém a nomenklatura jsou převzaty z práce BERAN (2002) a upraveny podle aktuální verze přehledu měkkýšů ČR (JUŘIČKOVÁ et al. 2007). 
U všech sebraných živých jedinců druhu Unio crassus byly zjišt'ovány rozměry jejich schránky (délka, šírka, výška). Zároveň byl na základě zimních délek schránky odhadnut jejich věk. Takto odhadnutý věk nemusí být přesný a vhodnější je použít schránek čerstvě uhynulých jedinců a po důkladném očištění a prosvícení lampou provedení spočtení zimních délek, následně odvodit růstovou křivku jedinců a na základě závislosti délky schránky na určeném věku odvodit věk pro měřené živé jedince (cf. DOUDA 2006). Tato metoda však nebyla použita ze dvou důvodů. V př́padě náhonu Bečvy ve Vsetíně nebyl sesbírán dostatečný počet čerstvých prázdných schránek a zároveň byl v obou náhonech zjištěn evidentně rozdílný růst jedinců podle obývaného mikrohabitatu, kdy se věk jedinců o stejné délce často lišil. $\mathrm{Z}$ tohoto důvodu zde uvádím jak délkovou (Obr. 3) tak i věkovou (Obr. 4) strukturu zaznamenaných jedinců.

\section{Charakteristika území}

Vsetínská Bečva pramení mezi Dupačkou a Oselnou ve výšce $870 \mathrm{~m}$ n.m. a po více než $58 \mathrm{~km}$ se spojuje s Rožnovskou Bečvou u Valašského Meziř́ičí ve výšce 288 m n.m. (VLČEK 1984). Koryto je na většině toku upraveno mnoha příčnými prahy a několika většími jezy. Dno koryta je tvořeno zejména hrubozrnnými sedimenty (balvany, kameny, štěrk), jemnozrnné písčité či písčitobahnité sedimenty se vyskytují ojediněle. Zejména v dolním toku pod Vsetínem vykazuje vizuálně voda i bahnité sedimenty známky silného organického znečistění. Do Vsetínské Bečvy ústí velké množství především drobných přítoků. Mezi nejvýznamnější přítoky Vsetínské Bečvy patří Senice ústící zleva do Bečvy u obce Ústí, pravostranný přítok Bystřička ústící u Bystřičky a levostranný přítok Ratibořka ústící do Bečvy u Jablůnky. $\mathrm{Na}$ Vsetínské Bečvě, příp. přítocích, bylo v minulosti uměle vytvořeno několik náhonů. Do dnešní doby se zachovaly na Bečvě 2 náhony. Prvním je asi 1,5 km dlouhý náhon mezi jezem u Huslenek a Hovězím. Tento náhon o šírce cca $2 \mathrm{~m}$ protéká autokempem „U Splavu“a následně vede podél Bečvy až do Hovězí, kde ústí do Hořanského potoka a ten následně po méně než $100 \mathrm{~m}$ do Bečvy. Na toku jsou 3 příčné objekty a asi $45 \mathrm{~m}$ je zatrubněno. Druhým náhonem je náhon ve Vsetíně. Začíná u jezu jižně od Vsetína a po průtoku částí Vsetína ústí do Rokytenky a ta následně do Bečvy. $\mathrm{Na}$ většině toku je jeho šírka 3 až $4 \mathrm{~m}$ a vybudovány byly 2 prŕíñé objekty. Dalším víceméně funkčním náhonem je náhon Hořanského potoka začínající v Hovězí prakticky na stejném místě na kterém ústí do Hořanského potoka první ze zmíněných náhonů. Do Bečvy ústí západně od Janové. Má velmi omezený průtok a šiŕka koryta je kolem $1 \mathrm{~m}$. Další náhony Bečvy jsou již nefunkční. Některé jsou ještě alespoň částečně zavodněné (náhon v Halenkově), z jiných zůstala jen část suchého koryta (náhon v Novém Hrozenkově). Přirozenými stanovišti v nivě Bečvy jsou také prameniště a pramenné stružky, kterých je velké množství.

Niva Vsetínské Bečvy je velni chudá na stojaté vody. Především větší stojaté vody prakticky neexistují. Výjimkou je např. vodní nádrž Stanovnice u Karolinky a štěrkovna Valašský Balaton u Nového Hrozenkova.

\section{Přehled lokalit}

V této části jsou uvedeny popisy jednotlivých lokalit. Údaje jsou řazeny následovně: číslo lokality, zeměpisné sourradnice, kód pole pro faunistické mapování (BUCHAR 1982, PRUNER \& MíKA 1996), název nejbližší obce, lokalizace a popis lokality, datum průzkumu. Lokality jsou rozděleny do skupin a $\mathrm{v}$ nich řazeny po proudu Vsetínské Bečvy.

\section{Vsetínská Bečva}

1 - 49²1'39" N, 18¹6'53" E, 6675, Velké Karlovice, Vsetínská Bečva u mostu v západní části Velkých Karlovic, 31.7.2007; 2 - 49²1'10" N, 18¹3'57" E, 6675, Karolinka, Vsetínská Bečva nad jezem pod ústím potoka Stanovnice, 30.7.2007; 3 - 49 $20^{\prime} 36^{\prime \prime} \mathrm{N}, 18^{\circ} 13^{\prime} 00^{\prime \prime} \mathrm{E}$, 6675, Nový Hrozenkov, Vsetínská Bečva nad jezem u začátku bývalého náhonu u štěrkovny Valašský Balaton mezi Novým Hrozenkovem a Karolinkou., 2.8.2007; 4 49²0'21" N, 18¹2'35" E, 6675, Nový Hrozenkov, Vsetínská Bečva jihovýchodně od železniční stanice Nový Hrozenkov, 2.8.2007; 5 - 49 $18^{\prime} 13^{\prime \prime} \mathrm{N}, 18^{\circ} 04^{\prime} 48^{\prime \prime}$ E, 6674, Hovězí, Vsetínská Bečva pod jezem u autokempu „U Splavu“ mezi Huslenky a Hovězím, 28.7.2007; 6 49¹8'30" N, 1803'38" E, 6674, Hovězí, Vsetínská Bečva pod ústím Hořanského potoka, 1.8.2007; 7 49¹8'40" N, 1801'15" E, 6674, Janová, Vsetínská Bečva u silničního mostu v Janové, 3.8.2007; 8 4918'43" N, 1800'13" E, 6674, Ústí, Vsetínská Bečva v Ústí u mostu, 22.8.2007; 9 - 49¹9'29" N, 1759'48" E, 6674, Vsetín, Vsetínská Bečva okolo jezu u začátku náhonu na jižním okraji Vsetína, 12.8.2007; 10 49²0'29" N, 1759'19" E, 6673, Vsetín, Vsetínská Bečva u ústí Rokytenky ve Vsetíně, 11.8.2007; 11 4921'02" N, 1758'08" E, 6673, Vsetín, Vsetínská Bečva pod silničním a železničním mostem na severozápadním okraji Vsetína, 11.8.2007; 12 - 49²1'47" N, 1757'03" E, 6673, Semetín, Vsetínská Bečva asi $200 \mathrm{~m}$ pod ústím Semetínského potoka, 11.8.2007; 13 4922'22" N, 1756'23" E, 6673, Jablůnka, Vsetínská Bečva u mostu silnice na Ratiboř, 11.8.2007; 14 49²5'09" N, 1757'39" E, 6573, Bystřička, Vsetínská Bečva pod mostem $\mathrm{v}$ Bystřičce, 22.8.2007; 15 49²6'14" N, 1757'54" E, 6573, Jarcová, Vsetínská Bečva u železniční zastávky Brňov, 22.8.2007; 16 49²7'09" N, 1757'20" E, 6573, Jarcová, Vsetínská Bečva u PP Bražiská, 22.8.2007; 17 - 49²7'56" N, 1757'21" E, 6573, Valašské Meziříčí, Vsetínská Bečva asi $300 \mathrm{~m}$ před soutokem s Rožnovskou Bečvou, 22.8.2007. 
Náhon Bečvy v Hovězí

18 - 49¹8'11" N, 1804'45" E, 6674, Hovězí, náhon Bečvy asi $50 \mathrm{~m}$ od svého začátku na okraji autokempu „U Splavu“ (u větší zelené chatky), 29.7.2007; 19 4918'11" N, 1804'44" E, 6674, Hovězí, náhon Bečvy v autokempu „U Splavu“ u mostku k umývárnám, 28.7.2007; 20 - 49¹8'11" N, 1804'43" E, 6674, Hovězí, náhon Bečvy na západním okraji autokempu „U Splavu" u silnice mezi autokempem a hotelem Koliba, 2.8.2007; 21 - 49 $18^{\circ} 12^{\prime \prime}$ N, 1804'41" E, 6674, Hovězí, náhon Bečvy pod hotelem Koliba, 1.8.2007; 22 4918'13" N, 1804'22" E, 6674, Hovězí, náhon Bečvy mezi Bradovským Mlýnem a mimoúrovňovým kř̌́žením s drobným potůčkem, 1.8.2007; 23 - 49 $18^{\circ} 14^{\prime \prime} \mathrm{N}$, 1804'19" E, 6674, Hovězí, náhon Bečvy u Bradovského Mlýna, 30.7.2007; 24 - 49¹8'14" N, 1804'17" E, 6674, Hovězí, náhon Bečvy pod malým jízkem mezi rybníkem a Bradovským Mlýnem, 30.7.2007; 25 - 49 ${ }^{\circ} 18^{\prime} 17^{\prime \prime}$ N, $18^{\circ} 04^{\prime} 01^{\prime \prime}$ E, 6674, Hovězí, náhon Bečvy pod malým rybníkem na východním okraji Hovězí, 30.7.2007; 26 49¹8'21" N, 1803'54" E, 6674, Hovězí, náhon Bečvy asi $150 \mathrm{~m}$ před mostem silnice v Hovězí, 1.8.2007; 27 4918'25" N, 1803'46" E, 6674, Hovězí, náhon Bečvy v Hovězí nad a pod silničním mostem, 29.7.2007; 28 4918'27" N, 1803'39" E, 6674, Hovězí, náhon Bečvy asi $10 \mathrm{~m}$ před ústím do Hořanského potoka (před dřevěným prríčným objektem), 1.8.2007.

Náhon Bečvy ve Vsetíně

29 - 49¹9'31" N, 1759'48" E, 6674, Vsetín, náhon Bečvy těsně pod jezem na svém začátku na jižním okraji

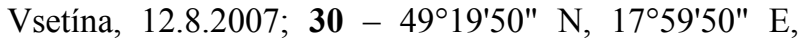
6673, Vsetín, náhon Bečvy u nemocnice u mostu silnice a nad přemostěním železniční trati, 3.8.2007; 31 49¹9'59" N, 1759'33" E, 6673, Vsetín, náhon Bečvy před mostkem Na Lapači (zhruba naproti hotelu Magion), 12.8.2007; 32 - 49 $20^{\prime} 05^{\prime \prime} \mathrm{N}, 1^{\circ} 59^{\prime} 26^{\prime \prime} \mathrm{E}, 6673$, Vsetín, náhon Bečvy u zimního stadionu, 12.8.2007; 33 - 49²0'09" N, 1759'24" E, 6673, Vsetín, náhon Bečvy pod jezem u starého mlýna či pily u malého parku, 12.8.2007; 34 - 49²0'16" N, 1759'25" E, 6673, Vsetín, náhon Bečvy před ústím do Rokytenky, 12.8.2007.

Náhon Bečvy v Halenkově a náhon Hořanského potoka v Hovězí

35 - 49 ${ }^{\circ} 19^{\prime} 34 "$ N, 1809'45" E, 6674, Halenkov, začátek bývalého náhonu Bečvy mezi jezem Halenkov a kř́žením s potokem, 24.3.2007; 36 - 49¹9'34" N, 1809'44" E, 6674, Halenkov, bývalý náhon Bečvy pod křižením s potokem asi $100-200 \mathrm{~m}$ pod jezem, 24.3.2007; 37 4919'31" N, 1809'40" E, 6674, Halenkov, bývalý náhon Bečvy u mostku silnice u školy, 24.3.2007; 38 $49^{\circ} 19^{\prime} 15^{\prime \prime} \mathrm{N}, 18^{\circ} 08^{\prime} 55^{\prime \prime} \mathrm{E}, 6674$, Halenkov, bývalý náhon Bečvy u hřiště, 24.3.2007; 39 - 49 $18^{\prime} 29^{\prime \prime} \mathrm{N}$, $18^{\circ} 03^{\prime} 30^{\prime \prime}$ E, 6674, Hovězí, náhon Hořanského potoka na západním okraji Hovězí, 1.8.2007; 40 - 49¹8'43" N,
1801'14" E, 6674, Janová, náhon Hořanského potoka u železniční zastávky Janová, 3.8.2007.

Př́toky Bečvy

41 - 49²1'34" N, 18¹7'08" E, 6675, Velké Karlovice, potok tekoucí od Pluskovce (levostranný prítok Bečvy) u železniční zastávky Velké Karlovice (zast.), 31.7.2007; 42 - 49 $19^{\circ} 43^{\prime \prime}$ N, 18²16'51" E, 6675, Velké Karlovice, Jezerní potok asi $100 \mathrm{~m}$ před ústím do Bečvy,

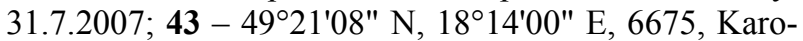
linka, potok Stanovnice před ústím do Bečvy, 30.7.2007; 44 - 49 $21^{\prime} 12^{\prime \prime}$ N, 18¹3'42" E, 6675, Karolinka, potok Kobylská před ústím do Bečvy, 30.7.2007; 45 4919'17" N, 18¹0'30" E, 6675, Nový Hrozenkov, potok Břežitá asi $700 \mathrm{~m}$ před ústím do Bečvy, 24.3.2007; 46 - 4918'56" N, 1809'10" E, 6674, Halenkov, Provazný potok na $\mathrm{J}$ okraji Halenkova, 24.3.2007; 47 $49^{\circ} 18^{\prime} 25^{\prime \prime} \mathrm{N}, 18^{\circ} 03^{\prime} 50^{\prime \prime} \mathrm{E}, 6674$, Hovězí, potok tekoucí z Hovízek asi $100 \mathrm{~m}$ před ústím do Bečvy, 29.7.2007; 48

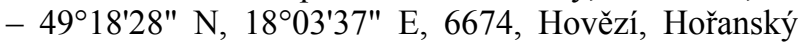
potok před ústím do Bečvy, 1.8.2007; $49-49^{\circ} 18^{\prime} 43^{\prime \prime} \mathrm{N}$, $18^{\circ} 01^{\prime} 14^{\prime \prime} \mathrm{E}, 6674$, Janová, drobný pravostranný prítok Bečvy v Janové asi $50 \mathrm{~m}$ před ústím do Bečvy, 3.8.2007; 50 - 49 $18^{\prime} 27^{\prime \prime} \mathrm{N}, 18^{\circ} 01^{\prime} 10^{\prime \prime}$ E, 6674, Janová, drobný př́tok náhonu u železniční zastávky Janová, 3.8.2007; 51 - 49 $20^{\prime} 16^{\prime \prime}$ N, 1759'23" E, 6673, Vsetín, Rokytenka nad ústím náhonu Bečvy, 12.8.2007; 52 - 49 $29^{\prime} 17^{\prime \prime} \mathrm{N}$, $17^{\circ} 59^{\prime 2} 23^{\prime \prime}$ E, 6673, Vsetín, Rokytenka pod ústím náhonu Bečvy, 12.8.2007; 53 - 49²0'27" N, 1759'22" E, 6673, Vsetín, Rokytenka před ústím do Bečvy, 11.8.2007; 54 49²1'37" N, 1757'14" E, 6673, Semetín, Semetínský potok před ústím do Vsetínské Bečvy, 11.8.2007; 55 49 $22^{\prime} 16^{\prime \prime}$ N, 17 $56^{\circ} 22^{\prime \prime}$ E, 6673, Jablůnka, Ratibořka pred ústím do Bečvy, 11.8.2007; 56 - 49²5'09" N, $17^{\circ} 57^{\prime} 50^{\prime \prime}$ E, 6673, Bystřička, Bystřička u železničního mostu před ústím do Bečvy, 22.8.200.

\section{Prameniště a vodní nádrže}

$57-49^{\circ} 18^{\prime} 31^{\prime \prime} \mathrm{N}, 18^{\circ} 10^{\prime} 39^{\prime \prime}$ E, 6675, Nový Hrozenkov, pramenná stružka pod samotou Pauci jihovýchodně od Halenkova, 24.3.2007; 58 - 49 $18^{\circ} 34^{\prime \prime}$ N, 18 $8^{\circ} 10^{\prime} 42^{\prime \prime}$ E, 6675, Nový Hrozenkov, pramenná stružka podél cesty v nivě př́toku potoka Břežitá, 24.3.2007; 59-4918'37" N, 18 $10^{\prime} 07^{\prime \prime}$ E, 6674, Halenkov, prameniště u lesní cesty nad nivou Provazného potoka asi 1500 m jihovýchodně od Halenkova, 24.3.2007; 60 - 49 $21^{\circ} 47^{\prime \prime} \mathrm{N}$, $17^{\circ} 57^{\prime} 03^{\prime \prime}$ E, 6673, Semetín, prameniště v břehu Vsetínské Bečvy asi $200 \mathrm{~m}$ pod ústím Semetínského potoka, 11.8.2007; 61 - 49 $26^{\prime} 13^{\prime \prime}$ N, 1757'49" E, 6573, Jarcová, prameniště u domu u Bečvy na opačné straně řeky než je železniční zastávka Brňov, 22.8.2007; 62 49²0'39" N, 18¹4'04" E, 6675, Karolinka, okolí hráze vodní nádrže Stanovnice, 30.7.2007; 63 - 49 $20^{\circ} 40^{\prime \prime} \mathrm{N}$, $18^{\circ} 13^{\prime} 02^{\prime \prime}$ E, 6675, Nový Hrozenkov, štěrkovna Valašský Balaton, 2.8.2007. 


\section{Dosavadní malakologické průzkumy}

Je s podivem, že z nivy Vsetínské Bečvy neexistují prakticky žádné údaje o výskytu vodních měkkýšủ před rokem 1998. Výjimkou je několik údajů Sylvestra Máchy uložených ve Slezském muzeu v Opavě, které se týkají výskytu praménky Bythinella austriaca. Po roce 1998 (1998, 2000, 2006) území navštívil L. Beran a v letech 1999 a 2000 M. Horsák. Zatímco údaje od prvního autora se týkají především náhonů Bečvy, kdy zde byl zjišstěn výskyt velevruba tupého a na základě těchto nálezů bylo území podrobněji zkoumáno v roce 2007, tak několik nálezů $M$. Horsáka pochází většinou $\mathrm{z}$ různých prameništ' a prameništních mokřadů a týkají se druhů Bythinella austriaca, Galba truncatula, Pisidium personatum, $P$. casertanum. Ve všech případech se jedná o dosud nepublikované údaje, které byly získány $\mathrm{z}$ autorovi databáze (viz kapitola Metodika a materiál).

\section{Výsledky a diskuse}

Přehled zjištěných druhů

V této části jsou uvedeny výsledky průzkumu podle jednotlivých druhů. U každého druhu je uveden kromě latinského názvu i český ekvivalent a zoogeografické rozšíření převzaté z práce BERAN (2002). Jsou zde uvedeny také údaje týkající se obývaných stanovišt', poznámky $\mathrm{k}$ rozšíření na území ČR a rozšíření ve sledované oblasti.

Tř́́da: Gastropoda

Řád: Neotaenioglossa

Čeled': Hydrobiidae

Potamopyrgus antipodarum (Gray, 1843) - písečník novozélandský. Druh zavlečený do Evropy z Nového Zélandu. V současnosti běžný a širíící se druh zejména v Polabí a severozápadních Čechách, na Moravě je zatím relativně vzácný (BERAN 2006b). Obývá především pískovny, odstavená ramena a vodní toky se štěrkopísčitými sedimenty. Zjišstěn byl ve štěrkovně Valašský Balaton a zoologicky se jedná o významný a překvapivý nález, který dokládá další šiřrení druhu i v oblasti Moravy a to i do míst, která jsou izolována od jiných vhodných lokalit v nižších polohách. Jeho výskyt zde dokládá schopnost dálkového šíření do vhodných biotopů (štěrkovny) i mimo současné oblasti výskytu v nivách velkých řek. $\mathrm{O}$ způsobu migrace do výše zmíněné lokality lze pouze spekulovat, ale možné způsoby jsou např. neúmyslné zavlečení člověkem (nafukovací hračky, čluny či matrace, plavky atd.) či dálkový přenos vodními ptáky.

Bythinella austriaca (Frauenfeld, 1857) - praménka rakouská. Východoalpsko-karpatský druh. Druh obývající prameniště a pramenné stružky. Ve zkoumané oblasti patř́i $\mathrm{k}$ běžným druhům a kromě prameništ' a pramenných stružek byla zjištěna i v několika větších př́tocích Bečvy.
Čeled': Bithyniidae

Bithynia tentaculata (Linnaeus, 1758) - bahnivka rmutná. Palearktický druh. Běžný druh pomaleji tekoucích a úživnějších vodních toků a neprríliš zazemněných a zarostlých stojatých vod. Nález jediného jedince $v$ Bečvě v Hovězí je překvapivý, nebot' tento druh preferuje nižší polohy a výrazně úživnější vody.

Řád: Hygrophila

Čeled': Lymnaeidae

Galba truncatula (O.F. Müller, 1774) - bahnatka malá. Holarktický druh. Běžný druh, který se obvykle vyskytuje na rozhraní mezi vodou a souší (břehy vodních toků, mokřady). Zjištěn byl na řadě lokalit.

Radix auricularia (Linnaeus, 1758) - uchatka nadmutá. Palearktický druh. Obývá velké spektrum biotopů kromě př́lišs zarostlých a zazemněných stojatých vod. Je typickým pionýrským druhem obnovených či nově vytvořených biotopů (pískovny). Běžný je i výskyt $\mathrm{v}$ pomaleji tekoucích vodách. Byl zjištěn v obou zkoumaných vodních plochách a vzácněji i v náhonu v Hovězí a Vsetíně a některých prítocích.

Radix peregra (O.F. Müller, 1774) - uchatka toulavá. Palearktický druh. Typický druh méně úživných vodních toků, nádrží a mokřadů. Ve sledovaném území byl zjištěn různě početně ve všech typech stanovišt' kromě stojatých vod.

Radix ampla (Hartmann, 1821) - uchatka široká. Palearktický druh. Plž charakteristický pro větší vodní toky, který patřil zejména $\mathrm{v}$ prrípadě Vsetínské Bečvy a náhonu ve Vsetíně k dominantním druhům.

Čeled': Physidae

Physella acuta (Draparnaud, 1805) - levatka ostrá. Druh zavlečený do Evropy ze Severní Ameriky. Vyskytuje se $\mathrm{v}$ různých typech stanovišt'. Běžně bývá nalézán i v silně znečištěných tocích či silně eutrofních nádržích. Zjištěna byla v Bečvě ve Vsetíně a níže po proudu. Zejména ve Vsetíně její početnější výskyt indikuje silné znečištění, které je patrné zejména na lok. č. 11.

Čeled': Planorbidae

Anisus leucostoma (Millet, 1813) - svinutec běloústý. Evropsko-západosibiřský druh. Typický obyvatel periodických tůní a mokřadů od nížin až po vyšší polohy, který byl nalezen $\mathrm{v}$ náhonu $\mathrm{v}$ Hovězí a zejména $\mathrm{v}$ téměř zazemněném náhonu v Halenkově.

Gyraulus albus (O.F. Müller, 1774) - kružník bělavý. Palearktický druh. Běžný druh na většině území ČR, který obývá široké spektrum biotopů a to zejména méně zarostlých. Je běžně zjišt'ován i v pomaleji tekoucích vodách a byl zjištěn především v níže položeném úseku Bečvy a méně $i v$ náhonech či prítocích Bečvy a také v obou zkoumaných nádržích. 
Gyraulus parvus (Say, 1817) - kružník malý. Druh původem ze Severní Ameriky. Nepůvodní druh, který se v současnosti v ČR intenzívně šírí do různých typů stanovišt'. Zjištěn byl v některých přítocích Bečvy a vlastní Bečvě mezi Vsetínem a Valašským Meziříčím. Jedná se o první nálezy v této oblasti a zároveň o první údaje $\mathrm{z}$ tekoucích a relativně málo úživných vod.

Gyraulus crista (Linnaeus, 1758) - ostníček žebernatý. Holarktický druh. Běžný druh obývající široké spektrum stanovišt' se stojatou vodou. Zjištěn byl ve vodní nádrži Stanovnice a ojediněle i v Bečvě ve Vsetíně.

Ancylus fluviatilis O.F. Müller, 1774 - kamomil říční. Evropský druh. Druh tekoucích vod, který preferuje proudné úseky s kamenitým dnem. Nejpočetněji a nejčastěji zastoupený druh v prrípadě Bečvy, jejích přítokůa náhonů Bečvy v Hovězí a Vsetíně.

Tř́ida: Bivalvia

Rád: Unionoida

Čeled': Unionidae

Unio crassus Philipsson, 1788 - velevrub tupý. Evropský druh. Celoevropsky ohrožený a zároveň evropsky významný druh, který obývá různě velké toky. V současnosti je známo v ČR asi 15 lokalit s perspektivními populacemi (např. BERAN 2002). Jak v náhonu Bečvy v Hovězí, tak i v náhonu Bečvy ve Vsetíně se podařilo ověřit výskyt tohoto druhu. $\mathrm{V}$ prípadě náhonu Bečvy v Hovězí byla největší početnost zjištěna $v$ asi $100 \mathrm{~m}$ dlouhém úseku na začátku náhonu v autokempu „U Splavu“, kde je odhadem v průměru cca 10 jedinců na $1 \mathrm{~m}$ toku. Maximální zjištěná početnost dosahovala 20 jedinců na $1 \mathrm{~m}^{2}$ (viz Obr. 1). Zejména $\mathrm{v}$ tomto úseku byl zjištěn i výskyt nejmladších stadií (o délce kolem 5 $\mathrm{mm})$. Postupně abundance klesala a odhadem je přibližně 1 jedinec na $1 \mathrm{~m}$ toku. Výjimkou je úsek před ústím do Hořanského potoka, kde byl zjištěn početnější výskyt. Celkově odhaduji početnost populace na 1500 2500 jedinců.

$\mathrm{Na}$ Obr. 3 je uvedena délka všech měřených jedinců, kde převažuje kategorie s délkou $35-40 \mathrm{~mm}$ a o něco méně jsou zastoupeny kategorie $30-35 \mathrm{~mm}$ a $40-45 \mathrm{~mm}$. $\mathrm{V}$ prrípadě věkové struktury je výrazná převaha kategorie jedinců s odhadovaným stárím 4 roky a to velmi výrazně ve srovnáním s jinými kategoriemi (Obr. 4). Tento graf je však nutné brát s určitou rezervou, nebot' věk byl odhadován podle zimních délek na živých jedincích - tzn. bez očištění př́ip. prosvícení lastur. Největší hustota populace v náhonu Bečvy ve Vsetíně byla zjištěna na lok. č. 30 a 31 (mezi nemocnicí a ulicí Na Lapači), kde bylo nalezeno 15 resp. 14 jedinců na $1 \mathrm{~m}^{2}$ a odhaduji koncentraci na min. 10 jedinců na $1 \mathrm{~m}$ toku (viz Obr. 2). Na zbylé části toku byly zjištěné koncentrace nižší a pohybovaly se okolo 1 jedince na $1 \mathrm{~m}$ toku. Celkově odhaduji velikost populace velevruba tupého v náhonu na 10004000 jedinců. Prakticky na všech lokalitách byla nalezena nejmladší stadia s délkou $2-10 \mathrm{~mm}$ a to $\mathrm{v}$ relativně velkém počtu (viz Obr. 3). Nejpočetněji byla zastoupena kategorie s délkou 45-50 mm a v př́padě věku opět kategorie jedinců s odhadovaným stářím 4 let s tím, že věková struktura zde byla vyrovnanější a s větším zastoupením nejmladších jedinců (Obr. 4). Výsledek však mohl být ovlivněn menším počtem jedinců ve vzorku. Výskyt početných populací velevruba tupého je z pohledu ochrany př́rody velmi významný, i když na Bečvě nikterak ojedinělý jak zjistil průzkum náhonu Strhanec (BERAN 2003) a Malé Bečvy (BERAN 2007).

Anodonta anatina (Linnaeus, 1758) - škeble říční. Eurosibiřský druh. Zřejmě nejběžnější velký mlž v rámci ČR, vyskytující se v tekoucích i větších stojatých vodách. Zjištěn byl pouze ve štěrkovně Valašský Balaton.

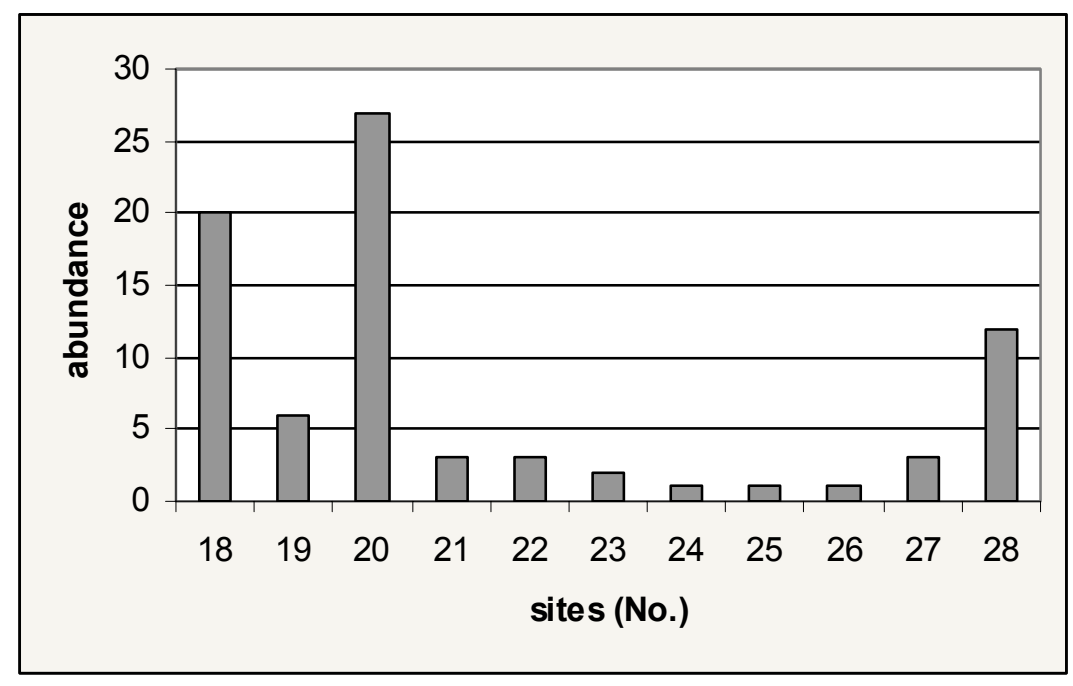

Obr. 1. Maximální zjištěná početnost velevruba tupého (Unio crassus) na jednotlivých lokalitách v náhonu v Hovězí (ex. na $\mathrm{m}^{2}$ ). Fig. 1. Highest documented abundance of Unio crassus at particular sites of the canal in Hovězí (individuals per $1 \mathrm{~m}^{2}$ ). 


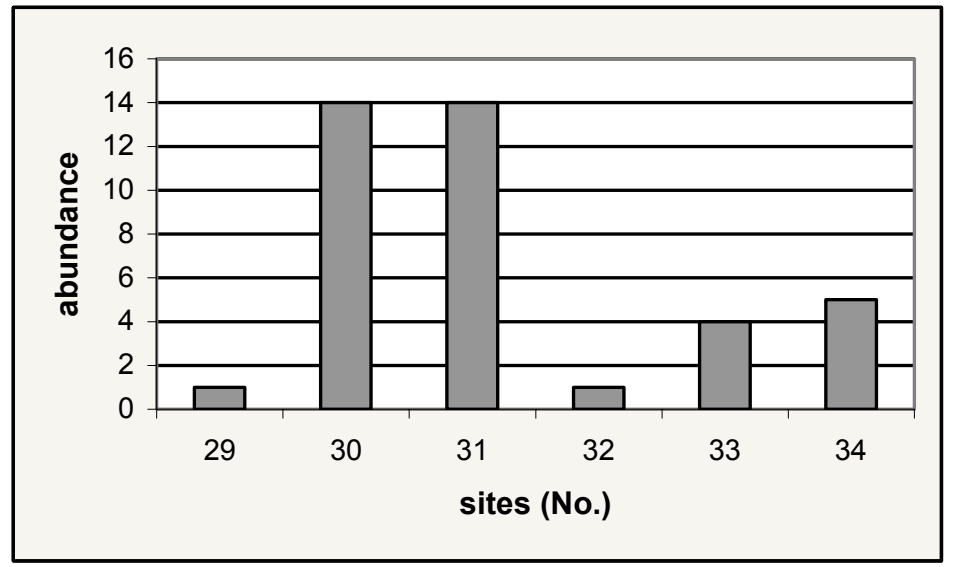

Obr. 2. Maximální zjištěná početnost velevruba tupého (Unio crassus) na jednotlivých lokalitách v náhonu ve Vsetíně (ex. na $\mathrm{m}^{2}$ ).

Fig. 2. Highest documented abundance of Unio crassus at particular sites of the canal in Vsetín (individuals per $1 \mathrm{~m}^{2}$ ).

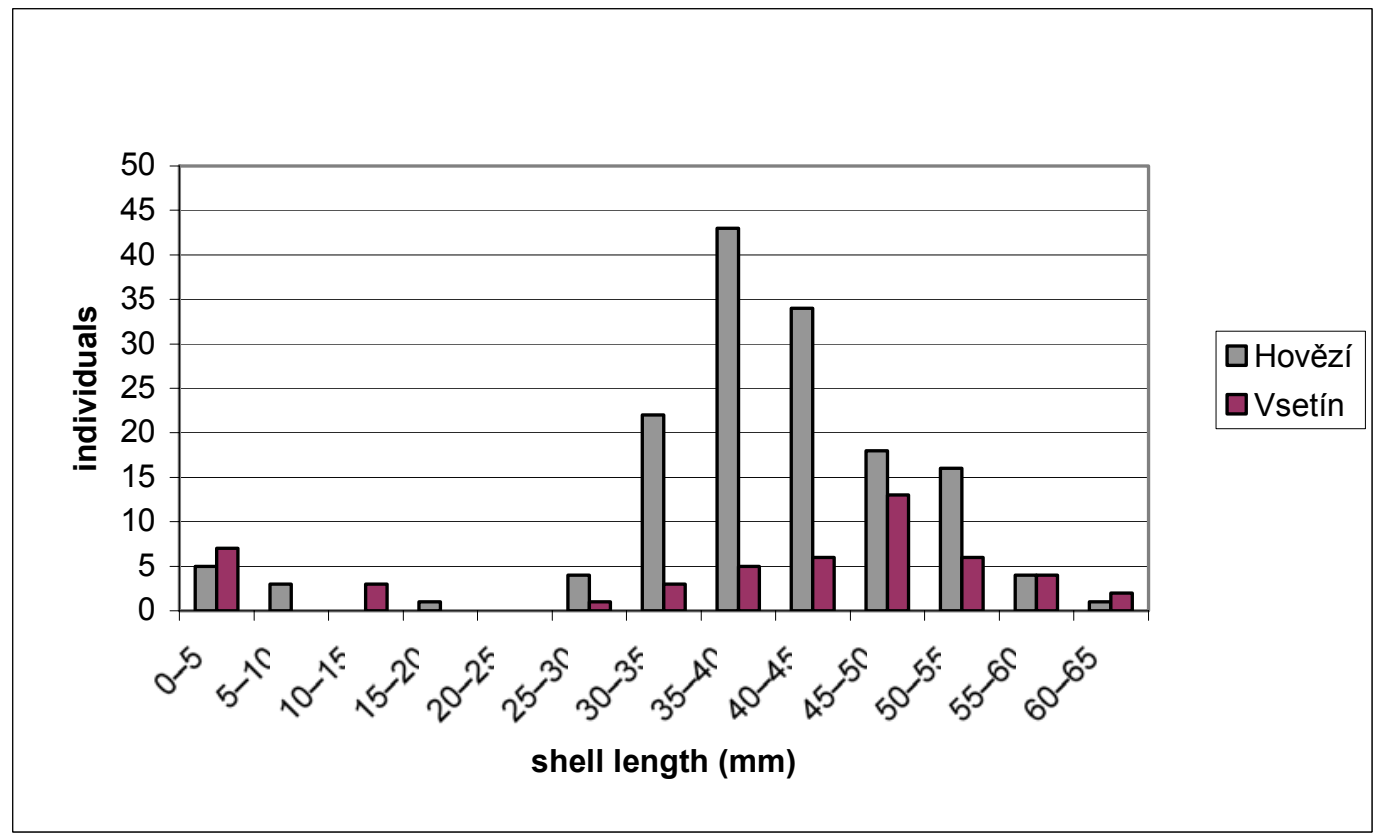

Obr. 3. Délka lastur zkoumaných jedinců velevruba tupého (Unio crassus) v náhonu v Hovězí a Vsetíně.

Fig. 3. Shell length of observed individuals of Unio crassus in canals (mill races) in Hovězí and Vsetín. 


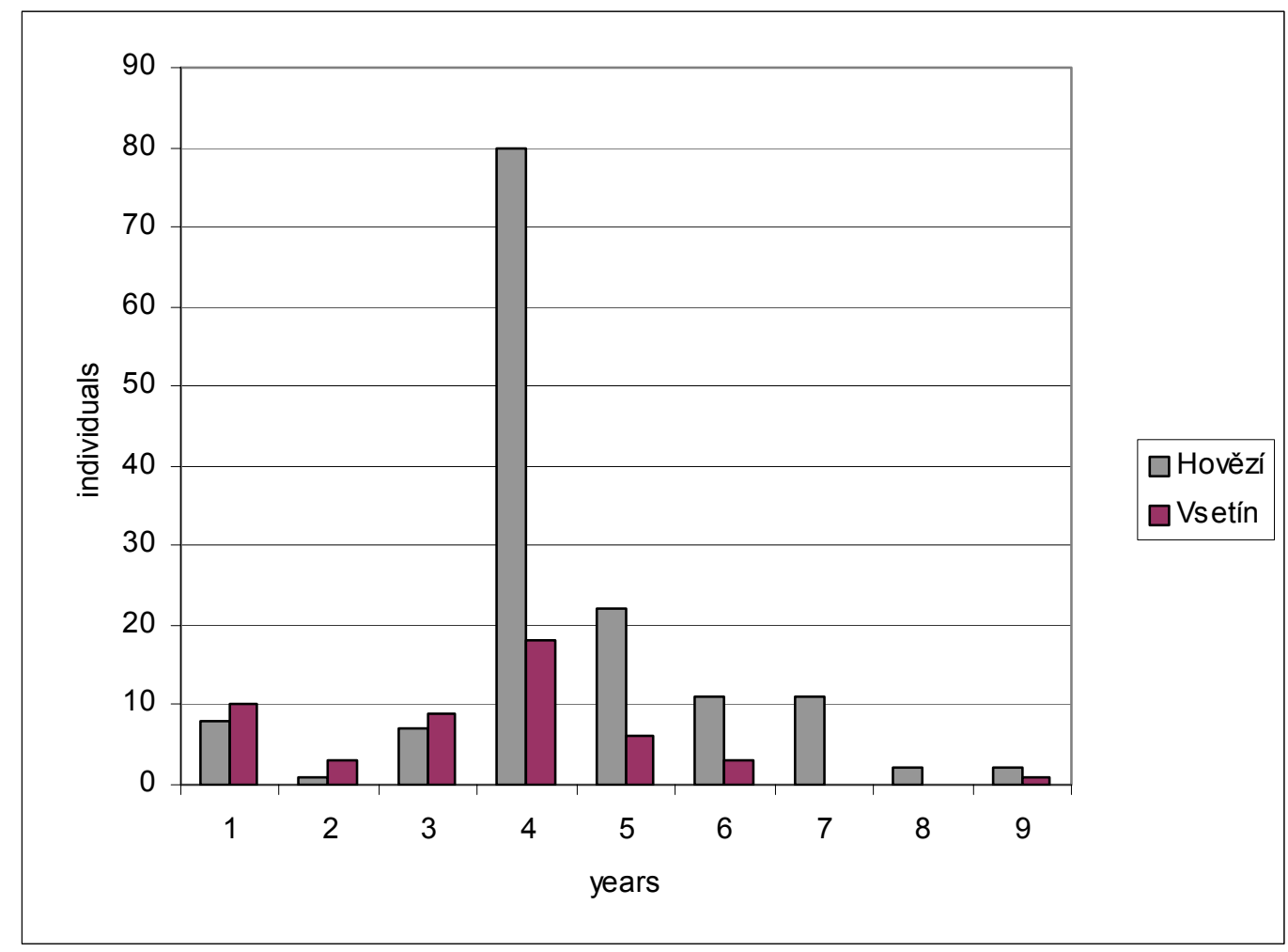

Obr. 4. Věková struktura zkoumaných jedinců velevruba tupého (Unio crassus) v náhonu v Hovězí a Vsetíně.

Fig. 4. Age structure of observed individuals of Unio crassus in canals (mill races) in Hovězí and Vsetín.

Řád: Veneroida

Čeled': Sphaeriidae

Pisidium amnicum (O. F. Müller, 1774) - hrachovka říční. Palearktický druh. Velmi vzácný druh vyskytující se ve vodních tocích s písčitobahnitým dnem. Na Moravě druh prakticky vymizel (cf. BERAN 2002) a je v současnosti znám pouze $\mathrm{z}$ níže po proudu položených náhonů Bečvy Strhanec u Přerova (BERAN 2003) a Malé Bečvy (BERAN 2007). V náhoně ve Vsetíně byl na jediné lokalitě zjištěn ojedinělý výskyt.

Pisidium subtruncatum Malm, 1855 - hrachovka otupená. Holarktický druh. Jedna $\mathrm{z}$ nejběžnějších hrachovek žijící především ve vodních tocích, ale také $\mathrm{v}$ řadě typů stojatých vod. Zjištěn byl zejména $v$ náhonech Bečvy v Hovězí a ve Vsetíně, v náhonu mezi Hovězím a Janovou a vzácně i ve vlastní Bečvě a některých prítocích.

Pisidium nitidum Jenyns, 1832 - hrachovka lesklá. Holarktický druh. Opět poměrně běžný druh. Zjištěn byl zejména $\mathrm{v}$ náhonech Bečvy $\mathrm{v}$ Hovězí, $\mathrm{v}$ náhonu mezi Hovězím a Janovou a vzácně i ve vlastní Bečvě.

Pisidium personatum Malm, 1855 - hrachovka malinká. Eurosibiřský druh. Typický druh drobných chladnějších a oligotrofních vod. Ve zkoumaném území byl zjištěn v prameništích a náhonu v Halenkově.

Pisidium casertanum (Poli, 1791) - hrachovka obecná. Pravděpodobně kosmopolitní druh. Zřejmě nejběžnější hrachovka rodu Pisidium v ČR, která se vyskytuje v řadě vodních stanovišt' od prameništ' a mokřadů až po velké vodní toky. Ve zkoumaném území zjištěna na 5 místech.

Pisidium moitessierianum (Paladilhe, 1866) - hrachovka nepatrná. Evropský druh. Vzácný druh, který je znám na Moravě pouze z jižní části Dolnomoravského úvalu (cf. BERAN 2002) a nově také $z$ náhonu Bečvy Strhanec (BERAN 2003) a Malé Bečvy (BERAN 2007). Vyskytuje se $\mathrm{v}$ písčitobahnitých sedimentech pomaleji tekoucích vodních toků a v náhonu ve Vsetíně byl ojediněle zjištěn na jediné lokalitě.

Průzkum nivy Vsetínské Bečvy v roce 2007 doložil výskyt 19 druhů vodních měkkýšů a to 12 druhů plžů a 7 druhů mlžů (Tabulka 1-5). V př́ípadě plžů je zřejmě nejpřekvapivějším zjištěním výskyt zavlečených druhů. Ve Vsetínské Bečvě pod Vsetínem a v některých přítocích byl zjištěn severoamerický druh Gyraulus parvus, který z této oblasti doposud nebyl znám (např. BERAN 2006a). Vsetínskou Bečvu mezi Vsetínem a Valašským Meziř́ićím obývá také severoamerická Physella acuta, jejíž výskyt $v$ tomto prípadě indikuje značné organické znečištění, které je patrné i vizuálně. Posledním nepůvodním plžem, zjištěným pro změnu ve štěrkovně Valašský Balaton je novozélandský druh Potamopyrgus 
antipodarum, který je na Moravě prozatím vzácný a z oblasti Beskyd není vůbec znám (např. BERAN 2006b). Ostatní zjištění plži patří $\mathrm{k}$ druhům běžným a typickým pro zkoumaná stanoviště. V Bečvě, většině přítoků a náhonů patří k typickým druhům především Ancylus fluviatilis, Galba truncatula a v př́padě vlastní Bečvy také vzácnější uchatka Radix ampla. Za zmínku stojí praménka Bythinella austriaca zjištěná v prameništích a některých vodních tocích. Tento předožábrý plž je však v této oblasti běžným prvkem a zcela jistě se vyskytuje v řadě dalších prameništ' a pramenných stružek. Zajímavé bylo také zjištění jediného jedince bahnivky Bithynia tentaculata ve Vsetínské Bečvě v Hovězí. Tento druh je běžným obyvatelem úživných vodních stanovišt', její nález zde je však překvapením. Složení společenstva mlžů je s výjimkou náhonů Bečvy a výskytu původně pontické slávičky Dreissena polymorpha ve šterkovně Valašský Balaton standardní. V prameništích a pramenných stružkách se vyskytuje hrachovka Pisidium personatum. Nejběžnější hrachovkou však je hrachovka Pisidium casertanum. Ostatní i když běžné hrachovky byly zjištěny mnohem méně. Důvodem je zejména ve vlastní
Bečvě a přítocích značná disturbance koryt a nevhodnost příliš hrubých sedimentů pro rozvoj společenstev mlžů. V náhonu ve Vsetíně byl zjištěn ojedinělý výskyt dvou vzácných hrachovek a to druhů Pisidium amnicum a $P$. moitessierianum. Oba tyto vzácné druhy byly v mnohem silnějších populacích zjištěny v níže po proudu situovaném náhonu Strhanec (BERAN 2003) a Malé Bečvě (BERAN 2007). Nejdůležitějším zjištěním je však potvrzení výskytu silných populací evropsky významného mlže velevruba tupého (Unio crassus) v náhonu Bečvy v Hovězí a Vsetíně. Náhony Bečvy jsou jediným místem zkoumaného území, kde byl tento druh zjištěn a tyto výskyty navazují na lokality na dolním toku Bečvy - náhon Strhanec (BERAN 2003) a Malou Bečvu (BERAN 2007). Vlastní tok Bečvy ani jeho prrítoky nejsou pravděpodobně vhodné stejně jako $\mathrm{v}$ případě drobných mlžů $\mathrm{z}$ důvodu častých a výrazných disturbancí a nedostatku vhodných sedimentů. Obě populace jsou vitální, početné a s výskytem nejmladších stadií. Pokud nedojde k nějakým nevhodným zásahům (vypuštění náhonů, odstraňování sedimentu, havárie atd.) jsou podmínky pro další existenci obou populací příznivé.

Tabulka 1. Přehled vodních měkkýšů na lokalitách: Vsetínská Bečva. Vysvětlivky: Latinský název, kategorie dle Červeného seznamu vodních měkkýšů ČR (BERAN et al. 2005, BERAN 2002), počet zjištěných jedinců na jednotlivých lokalitách, x(1) nález pouze staré lastury ( $v$ závorce počet).

Table 1. List of aquatic molluscs at localities: Vsetínská Bečva River. Explanations: Latin name, categories according to the Red List of aquatic molluscs of the Czech Republic (adopted from BERAN et al. 2005, BERAN 2002), number of individuals found at particular sites, $\mathrm{x}(1)$ old conch found only (number of conchs in parentheses).

\begin{tabular}{|c|c|c|c|c|c|c|c|c|c|c|c|c|c|c|c|c|c|c|}
\hline \multirow{2}{*}{\begin{tabular}{|l} 
Druh \\
(Species)
\end{tabular}} & \multirow{2}{*}{\begin{tabular}{|l|} 
Kategorie ohrožení \\
(Red List category) \\
\end{tabular}} & \multicolumn{17}{|c|}{ Lokalita č. (Loc. No.) } \\
\hline & & 1 & 2 & 3 & 4 & 5 & 6 & 7 & 8 & 9 & 10 & 11 & 12 & 13 & 14 & 15 & $\begin{array}{ll}16 \\
\end{array}$ & 17 \\
\hline Bithynia tentaculata & Málo dotčený (LC) & & & & & & 1 & & & & & & & & & & & \\
\hline Galba truncatula & Málo dotčený (LC) & 15 & 30 & 10 & 7 & 4 & 40 & 30 & 3 & 3 & 20 & 6 & & 3 & 7 & 4 & 80 & 15 \\
\hline Radix auricularia & Málo dotčený (LC) & & & & & & & & & & & & & & & & & \\
\hline Radix peregra & Málo dotčený (LC) & 40 & 35 & 50 & 6 & & 7 & 10 & 3 & & & & & & & & & \\
\hline Radix ampla & Téměř ohrožený (NT) & 70 & & 35 & 12 & 20 & 3 & 25 & 3 & 10 & & 8 & 8 & 8 & 6 & 20 & 3 & \\
\hline Physella acuta & Nevyhodnocený (NE) & & & & & & & & & & 4 & 30 & & & & 1 & 3 & 1 \\
\hline Gyraulus albus & Málo dotčený (LC) & & & & & & & 2 & & 40 & 3 & 7 & 3 & & 4 & 3 & 10 & 3 \\
\hline Gyraulus parvus & Nevyhodnocený (NE) & & & & & & & & & & & & & & & 2 & 6 & \\
\hline Gyraulus crista & Málo dotče & & & & & & & & & & 2 & & & & & & & \\
\hline Ancylus fluviatilis & Málo dotčený (LC) & 50 & 400 & 60 & 10 & 8 & 15 & 40 & 10 & 15 & 25 & 15 & 25 & 10 & 20 & 2 & 15 & 25 \\
\hline Pisidium subtruncatum & Málo dotčený (LC) & 1 & & 25 & & & & & & & & & & & & & & \\
\hline Pisidium nitidum & Málo dotčený (LC) & 2 & & & & & & & & & & & & & & & & \\
\hline Pisidium casertanum & Málo dotčený (LC) & 2 & 2 & 30 & & & & 3 & & & & & & & & & & \\
\hline Počet druhů na lokalitě & & 7 & 4 & 6 & 4 & 3 & 5 & 3 & 4 & 4 & 5 & 5 & 3 & 3 & 4 & 6 & 6 & 4 \\
\hline
\end{tabular}


Tabulka 2. Přehled vodních měkkýšů na lokalitách: náhon Vsetínské Bečvy v Hovězí. Vysvětlivky: viz Tabulka 1.

Table 2. List of aquatic molluscs at localities: canal of the Vsetínská Bečva River in Hovězí. Explanations: see Table 1.

\begin{tabular}{|l|l|c|c|c|c|c|c|c|c|c|c|c|}
\hline Druh & Kategorie ohrožení & \multicolumn{9}{|c|}{ Lokalita č. (Loc. No.) } \\
\hline (Species) & (Red List category) & 18 & 19 & 20 & 21 & 22 & 23 & 24 & 25 & 26 & 27 & 28 \\
\hline Bythinella austriaca & Zranitelný (VU) & & & & & & 2 & & & & & \\
\hline Galba truncatula & Málo dotčený (LC) & & & & & & & 10 & 8 & 15 & 8 & 12 \\
\hline Radix auricularia & Málo dotčený (LC) & & & & & & & 8 & & & 3 & \\
\hline Radix peregra & Málo dotčený (LC) & 8 & 8 & & 12 & 3 & 10 & 12 & 6 & 7 & 2 & 10 \\
\hline Radix ampla & Téměř ohrožený (NT) & 30 & & 10 & & & & 2 & & & & \\
\hline Anisus leucostoma & Málo dotčený (LC) & & & & & 5 & & 25 & & & & \\
\hline Gyraulus albus & Málo dotčený (LC) & & & & & 30 & 15 & 40 & & 10 & 30 & \\
\hline Ancylus fluviatilis & Málo dotčený (LC) & 50 & 12 & 12 & 40 & 15 & 40 & 40 & 5 & 30 & 20 & 6 \\
\hline Unio crassus & Ohrožený (EN) & 59 & 18 & 27 & 6 & 5 & 3 & 2 & 2 & 3 & 11 & 14 \\
\hline Pisidium subtruncatum & Málo dotčený (LC) & 10 & 8 & 10 & 8 & 10 & 8 & 10 & 6 & 8 & 3 & 7 \\
\hline Pisidium nitidum & Málo dotčený (LC) & 2 & 3 & 7 & 6 & & 2 & 4 & 3 & 4 & & 2 \\
\hline Pisidium casertanum & Málo dotčený (LC) & 30 & 15 & 18 & 20 & 40 & 25 & 30 & 15 & 15 & 1 & 10 \\
\hline Počet druhů na lokalitě & & 7 & 6 & 6 & 6 & 7 & 8 & 11 & 7 & 8 & 8 & 7 \\
\hline
\end{tabular}

Tabulka 3. Přehled vodních měkkýšů na lokalitách: náhon Vsetínské Bečvy ve Vsetíně a Halenkově a náhon Hořanského potoka v Hovězí. Vysvětlivky: viz Tabulka 1.

Table 3. List of aquatic molluscs at localities: canal of the Vsetínská Bečva River in Vsetín and Halenkov and canal of the Hořanský Potok stream in Hovězí. Explanations: see Table 1.

\begin{tabular}{|l|l|l|l|l|l|l|l|l|l|l|l|l|c|c|}
\hline Druh & Kategorie ohrožení & \multicolumn{9}{|c|}{ Lokalita č. (Loc. No. } \\
\hline (Species) & (Red List category) & 29 & 30 & 31 & 32 & 33 & 34 & 35 & 36 & 37 & 38 & 39 & 40 \\
\hline Bythinella austriaca & Zranitelný (VU) & & & & & & & & & 8 & & & \\
\hline Galba truncatula & Málo dotčený (LC) & & & & & & & 8 & 8 & 4 & & & 7 \\
\hline Radix auricularia & Málo dotčený (LC) & & & 1 & 1 & 1 & & & & & & & \\
\hline Radix peregra & Málo dotčený (LC) & 7 & & & & & & 5 & 3 & 3 & & & 20 \\
\hline Radix ampla & Téměř ohrožený (NT) & 20 & 8 & 6 & 3 & 12 & 10 & & & & & & 3 \\
\hline Anisus leucostoma & Málo dotčený (LC) & & & & & & & 25 & 60 & 40 & 4 & & \\
\hline Gyraulus albus & Málo dotčený (LC) & 5 & & & & & & 4 & & & & 30 & \\
\hline Ancylus fluviatilis & Málo dotčený (LC) & 30 & 20 & 15 & & 20 & 25 & & & & & & \\
\hline Unio crassus & Ohrožený (EN) & 1 & 50 & 14 & 2 & 9 & 7 & & & $\mathrm{x}(1)$ & & & \\
\hline Pisidium amnicum & Ohrožený (EN) & & 1 & & & & & & & & & & \\
\hline Pisidium subtruncatum & Málo dotčený (LC) & & 8 & 2 & 1 & 6 & 3 & & & & & 15 & 10 \\
\hline Pisidium nitidum & Málo dotčený (LC) & & & & & & & & & & & 8 & \\
\hline Pisidium personatum & Málo dotčený (LC) & & & & & & & 5 & 5 & 3 & & & \\
\hline Pisidium casertanum & Málo dotčený (LC) & & 12 & 3 & 5 & 8 & 8 & 30 & 40 & 15 & & 40 & 250 \\
\hline Pisidium moitessierianum & Ohrožený (EN) & & 3 & & & & & & & & & & \\
\hline Počet druhů na lokalitě & & 5 & 7 & 6 & 5 & 6 & 5 & 6 & 5 & $6(7)$ & 1 & 4 & 5 \\
\hline
\end{tabular}

Tabulka 4. Přehled vodních měkkýšů na lokalitách: př́toky Vsetínské Bečvy. Vysvětlivky: viz Tabulka 1.

Table 4. List of aquatic molluscs at localities: tributaries of the Vsetínská Bečva River. Explanations: see Table 1.

\begin{tabular}{|l|l|l|l|l|l|l|l|l|l|l|l|l|c|c|c|c|c|}
\hline Druh & Kategorie ohrožení & \multicolumn{1}{|c|}{ Lokalita č. (Loc. No.) } \\
\hline (Species) & (Red List category) & 41 & 42 & 43 & 44 & 45 & 46 & 47 & 48 & 49 & 50 & 51 & 52 & 53 & 54 & 55 & 56 \\
\hline Bythinella austriaca & Zranitelný (VU) & & & & & & 7 & 8 & & & & & & & & & \\
\hline Galba truncatula & Málo dotčený (LC) & & & & & & & 8 & 15 & 40 & & & 10 & & 13 & & 7 \\
\hline Radix auricularia & Málo dotčený (LC) & & & & & & & & 3 & & & & 2 & & & & \\
\hline Radix peregra & Málo dotčený (LC) & & 8 & 7 & & & 1 & & 20 & 40 & 50 & & & & & & 15 \\
\hline Radix ampla & Téměř ohrožený (NT) & & & & & & & & 7 & & & & & & & 12 & \\
\hline Gyraulus albus & Málo dotčený (LC) & & & & & & & & 10 & & & & & & 10 & 4 & \\
\hline Gyraulus parvus & Nevyhodnocený (NE) & & & & & & & & & & & & & & 10 & 8 & 7 \\
\hline Ancylus fluviatilis & Málo dotčený (LC) & 7 & 15 & 150 & 80 & 10 & 12 & 3 & 30 & & & 25 & 15 & 10 & & 20 & 60 \\
\hline Unio crassus & Ohrožený (EN) & & & & & & & & & & & & 2 & & & & \\
\hline Pisidium casertanum & Málo dotčený (LC) & & & & & 3 & & 3 & 10 & 4 & & & 2 & & 3 & 3 & 5 \\
\hline Počet druhů na lokalitě & & 1 & 2 & 2 & 1 & 2 & 3 & 4 & 7 & 3 & 1 & 1 & 5 & 1 & 4 & 5 & 5 \\
\hline
\end{tabular}


Tabulka 5. Přehled vodních měkkýšů na lokalitách: prameniště a vodní nádrže. Vysvětlivky: viz Tabulka 1. Table 5. List of aquatic molluscs at localities: springs and water reservoirs. Explanations: see Table 1.

\begin{tabular}{|l|l|c|c|c|c|c|c|c|}
\hline Druh & Kategorie ohrožení & \multicolumn{6}{|c|}{ Lokalita č. (Loc. No.) } \\
\hline (Species) & (Red List category) & 57 & 58 & 59 & 60 & 61 & 62 & 63 \\
\hline Potamopyrgus antipodarum & Nevyhodnocený (NE) & & & & & & & 15 \\
\hline Bythinella austriaca & Zranitelný (VU) & 4 & 40 & 10 & 4 & 15 & & \\
\hline Galba truncatula & Málo dotčený (LC) & & 8 & & 8 & & 7 & \\
\hline Radix auricularia & Málo dotčený (LC) & & & & & & 25 & 7 \\
\hline Radix peregra & Málo dotčený (LC) & & & & & 3 & & \\
\hline Gyraulus albus & Málo dotčený (LC) & & & & & & 6 & 20 \\
\hline Gyraulus parvus & Nevyhodnocený (NE) & & & & & & & \\
\hline Gyraulus crista & Málo dotčený (LC) & & & & & & 30 & \\
\hline Ancylus fluviatilis & Málo dotčený (LC) & & & & 6 & & & \\
\hline Anodonta anatina & Málo dotčený (LC) & & & & & & & 3 \\
\hline Pisidium subtruncatum & Málo dotčený (LC) & & & & & & & 30 \\
\hline Pisidium personatum & Málo dotčený (LC) & 20 & 60 & & & 10 & & \\
\hline Pisidium casertanum & Málo dotčený (LC) & 30 & & & & 10 & & \\
\hline Dreissena polymorpha & Nevyhodnocený (NE) & & & & & & & 600 \\
\hline Počet druhů na lokalitě & & 3 & 3 & 1 & 3 & 4 & 4 & 6 \\
\hline
\end{tabular}

\section{Literatura}

BERAN L., 2002: Vodní měkkýši České republiky - rozšíření a jeho změny, stanoviště, šíření, ohrožení a ochrana, červený seznam [Aquatic molluscs of the Czech Republic - distribution and its changes, habitats, dispersal, threat and protection, Red List]. - Sborník př́rodovědného klubu v Uh. Hradišti, Supplementum 10, $258 \mathrm{pp}$.

BERAN L., 2003: Vodní měkkýši náhonu Strhanec (střední Morava) [Aquatic molluscs of the Strhanec Canal (Central Moravia, Czech Republic)]. - Bulletin Lampetra, 5: 22-26.

BERAN L., 2006a: Gyraulus parvus (Say, 1817) - kružník malý. - In: Nepůvodní druhy fauny a flóry České republiky, MlíkovskÝ J. \& StÝBlo P. (eds) ČSOP, Praha, pp. 219-220.

BERAN L., 2006b: Potamopyrgus antipodarum (Gray, 1843) písečník novozélandský. - In: Nepůvodní druhy fauny a flóry České republiky, MlíkovskÝ J. \& STÝBlo P. (eds) ČSOP, Praha, pp. 221-222.

BERAN L., 2007: Vodní měkkýši Malé Bečvy (Česká republika) [Aquatic molluscs of the Malá Bečva River (Czech Republic)]. - Malacologica Bohemoslovaca, 6: 29-34. Online serial at $<$ http://mollusca.sav.sk> 7-September-2007.

BERAN L., JUŘIČKOVÁ L. \& HorSÁK M., 2005: Mollusca
(Měkkýši), pp. 69-74. - In: Červený seznam ohrožených druhů České republiky. Bezobratlí. Red list of threatened species in the Czech Republic. Invertebrates, FARKAČ J., KRÁL D. \& ŠKORPíK M. (eds) Agentura ochrany př́rody a krajiny ČR, Praha, $760 \mathrm{pp}$.

BUCHAR J., 1982: Způsob publikace lokalit živočichů z území Československa. - Věst. Čs. Společ. Zool., Praha, 46: 317 318.

DOUDA K., 2006: Mlži čeledi Unionidae v lotických biotopech povodí Lužnice. - Ms., dipl. práce, Fakulta lesnická a environmentální ČZU Praha, 78 pp.

JuŘiČKOVÁ L., HorsáK M., BERAN L. \& DVOŘÁK L., 2007 : Check-list of the molluscs (Mollusca) of the Czech Republic. http://www.mollusca.sav.sk/malacology/checklist.htm.

PRUNer L. \& MíkA P., 1996: Seznam obcí a jejich částí v České republice s čísly mapových polí pro sítové mapování fauny [List of settlements in the Czech Republic with associated map field codes for faunistic grid mapping system]. - Klapalekiana, 32, Suppl.: 1-175.

VLČEK V. (ed.), 1984: Vodní toky a nádrže. Zeměpisný lexikon ČSR. - Academia, Praha, 316 pp. 